\title{
FORMATION OF BUDGET EXPENDITURE IN THE SYSTEM OF FISCAL REGULATION
}

\author{
Igor Chugunov', Valentina Makohon², Valerii Korovii ${ }^{3}$
}

\begin{abstract}
The purpose of the article is to substantiate scientific and methodological approaches to the development of a financial and budgetary strategy for budget expenditures in the context of globalization of the economy. The comparative and factor method allowed to reveal the peculiarities of the financial and budgetary strategy of forming the budget expenditures of the EU and Ukraine in the system of public finance management, to determine approaches for its improvement. Methodology. The substantiation of scientific and methodological approaches to the development of the financial and budgetary strategy of budgeting in the conditions of globalization of the economy is based on the generalization and systematization of the relevant instruments and instruments of the financial and budgetary strategy in the countries with advanced and transformative economies. To this end, the analysis and evaluation of budget architecture in terms of expenditures in different countries was done. Results. The results showed that the financial and budgetary strategy for budget expenditures is a comprehensive, adaptive system of directions and tasks of public administration in the sphere of budgeting expenditures to socio-economic transformations, which aims at improving the welfare of the population and the efficiency of the national economy. To accelerate economic growth, the EU countries are changing the structure of public sector spending in favor of productive ones, while optimizing unproductive spending. In particular, there is an increase in government capital investment. Long-term financial and budgetary sustainability should be assessed based on a system of thresholds for both budget expenditures and revenues; the increase in government spending should not exceed GDP growth. Practical implications. The financial and budgetary strategy is the target of the reproduction process. An adequate level of reasonableness of the architectonics of budget expenditures will contribute to ensuring the dynamic balance and stability of the budget system. It is advisable to make institutional changes to the architecture of budget expenditures based on an assessment of the dynamic interrelation of macroeconomic and budgetary indicators. There is an important task to develop economic and mathematical models based on the analysis and evaluation of macroeconomic proportions and the level of devel-opment of social production. Value/originality. Substantiation of scientific and methodological approaches to the development of financial and budgetary strategy for budget expenditures in the context of globalization of the economy is an important condition for ensuring macroeconomic stability and social development. To increase the feasibility of architectonics of budget expenditures, it is advisable to optimize them, to increase the share of productive costs and to reduce unproductive ones, to reconcile the dynamics of budget expenditures with macroeconomic indicators. Based on the aforementioned in this article, substantiated scientific and methodological approaches to the development of financial and budgetary strategy for budgeting expenditures in the context of strengthening globalization processes and their impact on the financial and budget sphere; approaches to improving the system of fiscal regulation in terms of budget expenditures are revealed, and it is determined that the soundness of the budget expenditures architectonics is the basis for the formation and implementation of effective fiscal policy, which determines the effectiveness of changes in the public finance system.
\end{abstract}

Key words: budget, budget expenditures, fiscal policy, budget system, budget architectonics.

JEL Classification: E63, H50, H61

\footnotetext{
Corresponding author:

${ }^{1}$ Kyiv National University of Trade and Economics, Ukraine.

E-mail: chugunov055@gmail.com

ORCID: http://orcid.org/0000-0003-4915-1267

${ }^{2}$ Kyiv National University of Trade and Economics, Ukraine.

E-mail: makvknteu@gmail.com

ORCID: http://orcid.org/0000-0002-2331-8455

${ }^{3}$ Kyiv National University of Trade and Economics, Ukraine.

E-mail: koroviy@vmr.gov.ua

ORCID: http://orcid.org/0000-0002-0625-6547
} 


\section{Introduction}

Updating the issues of developing a fiscal strategy for budget expenditures at the beginning of the 21 st century was prompted by increased attention to the longterm impact of political, economic and demographic challenges on the public finance system. Initially, fiscal strategies for budget expenditures were developed in countries with developed economies, and later in emerging countries. The importance of developing a fiscal strategy for budget expenditures is explained by the growing importance of challenges that violate the sustainability and stability of the public finance system and threaten the future socio-economic development of countries. The reduction in economic growth caused by the financial and economic crisis processes, raising pension load (caused by aging) increases the risk of destabilization of public finances and reinforces the need to address funding problems of socio-economic development orientation of fiscal strategy for budget expenditures to economic growth; improving the level of stability of public finances whereby public authorities will be able to fulfill their expenditure obligations without increasing the tax burden.

The validity of fiscal strategy for budget expenditures envisages its quantitative and qualitative assessment of the long term. However, significant attention is paid to change their structure over time, the relationship with macroeconomic variables. In particular, the EuroPlus Pact identifies the need for greater efforts and coordination of public authorities in achieving longterm sustainability of public finances, which provides for an adequate structure of government spending that will guarantee sustainability when increasing potential economic growth (Euro-Plus Pact, 2011). In this context, the fiscal strategy for budget expenditures should aim to create conditions that will help to increase employment and attract investment while maintaining a position close to the budgetary equilibrium.

Thus, the research problem is: what role of budget expenditures is in the system of fiscal regulation of economicprocesses, what directions of changes in scientific and methodological approaches are to the development of the financial and budgetary strategy will contribute to the dynamic balance, and stability of the budget system in the context of globalization of the economy.

\section{Scientific and methodological approaches to the development of the fi-nancial and budgetary strategy for budgeting}

A lot of scientists study the theoretical and methodological aspects of developing a fiscal strategy for budget expenditures. At the same time, the issues of its optimal structure, architectonics, and influence on the level of economic growth remain unresolved.

According to researchers, effective use of tools of budgetary strategy for budgeting helps to stabilize macroeconomic processes (Olanubi, Osode \& Adegboye, 2019); the validity of fiscal stabilization programs in budget expenditures plays an important role in ensuring macroeconomic stability and eliminating structural fiscal imbalances (Hu \& Zarazaga, 2018); the prudence of government spending contributes to accelerating economic growth (European Commission, 2002 and 2004; Lin \& Zhu, 2019). At the same time, uncertainty in government spending policy has a negative impact on economic activity (Kim, 2019; López, Galinato \& Islam, 2011).

Budget capital expenditures play a significant role in stimulating economic growth. In particular, it is argued that the intensity of research and development contributes to accelerating economic growth (Pop Silaghi, Alexa, Jude \& Litan, 2014). Public investments are classified as expenses that are most directly related to the acceleration of economic growth. However, their productivity depends largely on the nature of innovation and investment projects (The Quality of Public Expenditures in the EU, 2012; Ricco, Callegari \& Cimadomo, 2016).

Also, socio-economic policies of many countries are aimed at accelerating economic growth, limiting government spending on education, science, and technology, leading to stagnation of human capital and technological progress, limiting long-term economic growth (Liu \& Xu \& Yu \& Rong \& Zhang, 2019; Pasichnyi, 2017). In this connection, the important questions are estimating the relationship between the size and composition of government spending and the sectoral composition of employment in the economy. Government production spending is determined to influence long-term growth rates by their size and composition, both directly by increasing productivity and indirectly by changing the sectoral composition of the economy (Felice, 2016). Increasing spending on health, education, and transportation at constant total costs contribute to accelerating economic growth. Increasing the share of spending on housing and communal services has a negative impact on economic growth. The impact of changing the structure of government spending on economic growth is fully realized after five years (Barbiero \& Cournède, 2013). At the same time, it is important to find the optimal configuration of expenditure decentralization measures, given the institutional capacity of local governments and the level of economic development of regions (Pasichnyi, Kaneva, Ruban \& Nepytaliuk, 2019; Burge \& Rogers, 2011).

Fiscal and monetary policy reconciliation tasks are important in the context of the multifaceted impact of budget expenditures on the social and economic development of countries. As inflationary processes can be activated both by monetary policy measures (demand inflation) and by price increases by public authorities, in particular, petroleum products (cost inflation) (Yong \& Dingming, 2019). 
Government spending architecture plays a significant role in preventing intergenerational mobility by offsetting the effects of income inequality (Nam, 2019; Flavin, 2019). At the same time, scientists argue that the multiplier of government spending changes over time. Accordingly, the fiscal strategy for budget expenditures should take into account the phases of the economic cycle when assessing their effectiveness (Glocker, Sestieri \& Towbin, 2019). The multiplier effect of increasing production costs is 1.3 per year and 1.2 per three years. However, the effect is quite divergent in different countries depending on the particularities of the economic environment and the institutional context. In this case, the cost multiplier is larger during the recession period; expenditures have a relatively greater impact on the state with "medium" requirements for a balanced budget than those with weak or strong requirements; the cost multiplier is relatively smaller for states with weak or severe constraints on public debt levels than those with moderate reserves (Atems, 2019; Dupaigne \& Fève, 2016).

Thus, the issues of developing an effective scientific and methodological ap-proach to the fiscal strategy for budget expenditures in a globalizing economy remain unresolved.

\section{Special projects that are added to the budget in the fiscal regulation of the EU country}

The globalization of the economy leads to the creation of new socio-economic conditions, which should be guided by the methodology of financial and budgetary regulation of social relations. Crisis processes in the financial sphere indicate the need to increase the efficiency of the public finance management system, which is currently characterized by instability and reflects the crisis state of the reproduction process. The public finance system and its constituents operate under the weight of political priorities, especially in emerging countries. However, in the context of economic transformation, this is a prerequisite for the disproportionate regional development of countries and the unreasonableness of government spending structure. Also, the urgent need to justify reforms through the fiscal strategies development (in particular for budget expenditures) was driven by the crisis that occurred in 2008-2009. The fiscal strategy for budget expenditures should help to increase its balance because it is a necessary condition for ensuring macroeconomic stability and accelerating economic growth. Decisionmaking by public authorities on the use of budgetary funds is intended to ensure the implementation of public functions at the proper level in the context of limited revenues.

To determine the effective vectors of the fiscal strategy for budget expendi-tures, it is necessary to justify the thresholds of key fiscal indicators in this area.
In particular, the European Commission has developed a system of key indicators of financial sustainability, which is the basis for determining the thresholds for financial and budgetary indicators, including budget expenditures (The Long-Term Sustainability of Public Finances in the European Union, 2006).

Scientific research covers the budget revenues issues first and foremost. At the same time, the problems of the validity of the budget expenditures architectonics, their structure, and thresholds remain unprocessed. Assessment of the specificity of its formation in the long term is necessary for justifying the threshold values of budget expenditures, their architectonics. When analyzing the limits of budget expenditures, it is advisable to pay attention to the coherence of their growth rates with GDP growth rates, the share of capital expenditures in the general structure of expenditures.

Studying the scientific literature on these issues leads to the conclusion that in most cases, the architectonics of budget expenditures is determined by expert estimates based on world indicators and trends, as well as the specifics of the national economy. Economic and mathematical modeling, in particular, simulation models, is used to achieve this goal. Expenditure estimation (using simulation models) is relevant only for a certain period and should be updated as the longterm forecast of the socio-economic development of countries. At the same time, to achieve the goal of the fiscal strategy for budget expenditures, public authorities must, first of all, make relevant decisions about spending a certain amount of budget funds (which should be sufficient to ensure that citizens' constitutional rights and freedoms) in a certain direction.

In particular, in the EU countries, the share of government spending in GDP for 2007-2018 was $47.57 \%$, including $47.10 \%$ for $2007-2009$, $49.23 \%$ for $2010-2012,47.90 \%$ for $2013-2015,46.03 \%$ for 2016-2018 (Table 1).

The highest corresponding indicator for 20072018 is observed in the following countries: $56.13 \%$ in France, $54.04 \%$ in Denmark, $53.72 \%$ in Finland, $53.53 \%$ in Belgium, $52.01 \%$ in Greece. The smallest: $33.20 \%$ in Switzerland, 36.78\% in Romania, 37.19\% in Lithuania, 37.24\% in Bulgaria. The highest GDP per capita is observed in the following countries: $169.08 \%$ in Norway, $160.42 \%$ in Switzerland, 149.33\% in Ireland, 133.33\% in the Netherlands. The smallest: $45.83 \%$ in Bulgaria, $54.58 \%$ in Romania, $60.50 \%$ in Croatia, $60.50 \%$ in Latvia.

Budget expenditures issue is optimized in the context of strengthening or weakening the role of public authorities in regulating socio-economic processes, and there is an alternation of liberal and regulatory economic models that differ in their degree and nature of the impact on the economy. The regulatory model is characterized by the active role of public authorities in regulating the 
Vol. 6, No. 2, 2020

Baltic Journal of Economic Studies

Table 1

The share of government spending to GDP and GDP per capita of the EU countries, \%

\begin{tabular}{|c|c|c|c|c|c|c|c|c|}
\hline \multirow[b]{2}{*}{ Geography $\backslash$ Period } & \multicolumn{2}{|c|}{ 2007-2009 } & \multicolumn{2}{|c|}{$2010-2012$} & \multicolumn{2}{|c|}{ 2013-2015 } & \multicolumn{2}{|c|}{ 2016-2018 } \\
\hline & $\begin{array}{l}\text { Expenditur } \\
\% \text { of GDP }\end{array}$ & $\begin{array}{l}\text { GDP per } \\
\text { capita in } \\
\text { PPS }^{*}\end{array}$ & $\begin{array}{l}\text { Expenditur } \\
\% \text { of GDP }\end{array}$ & $\begin{array}{l}\text { GDP per } \\
\text { capita in } \\
\text { PPS* }^{*}\end{array}$ & $\begin{array}{l}\text { Expenditur } \\
\% \text { of GDP }\end{array}$ & $\begin{array}{l}\text { GDP per } \\
\text { capita in } \\
\text { PPS }^{*}\end{array}$ & $\begin{array}{l}\text { Expenditur } \\
\% \text { of GDP }\end{array}$ & $\begin{array}{l}\text { GDP per } \\
\text { capita in } \\
\text { PPS }^{*}\end{array}$ \\
\hline EU ( 28 countries $)$ & 47.10 & 100.00 & 49.23 & 100.00 & 47.90 & 100.00 & 46.03 & 100.00 \\
\hline Euro area (19 countries) & 47.77 & 108.33 & 50.10 & 107.67 & 49.20 & 106.33 & 47.30 & 106.00 \\
\hline Euro area (18 countries) & 47.80 & 109.33 & 50.10 & 107.67 & 49.23 & 106.67 & 47.30 & 106.33 \\
\hline Belgium & 51.37 & 116.00 & 55.23 & 119.33 & 55.13 & 120.00 & 52.37 & 118.00 \\
\hline Bulgaria & 38.03 & 42.00 & 34.90 & 45.00 & 40.53 & 46.33 & 35.50 & 50.00 \\
\hline Czechia & 41.73 & 83.67 & 43.67 & 82.67 & 42.23 & 85.33 & 39.70 & 89.00 \\
\hline Denmark & 52.17 & 124.33 & 57.03 & 128.00 & 55.17 & 127.33 & 51.80 & 127.33 \\
\hline Germany & 45.27 & 116.00 & 46.07 & 121.33 & 44.40 & 123.67 & 44.43 & 122.67 \\
\hline Estonia & 39.57 & 67.67 & 38.67 & 70.00 & 38.30 & 76.33 & 39.30 & 78.67 \\
\hline Ireland & 41.57 & 137.00 & 51.30 & 130.00 & 35.60 & 148.33 & 26.40 & 182.00 \\
\hline Greece & 50.67 & 93.33 & 54.13 & 77.00 & 55.43 & 70.33 & 47.80 & 67.67 \\
\hline Spain & 42.30 & 101.33 & 46.97 & 92.33 & 44.93 & 89.33 & 41.77 & 91.33 \\
\hline France & 54.37 & 107.33 & 56.77 & 107.67 & 57.07 & 106.67 & 56.33 & 104.00 \\
\hline Croatia & 46.77 & 62.00 & 48.60 & 59.67 & 48.53 & 59.00 & 46.37 & 61.33 \\
\hline Italy & 48.57 & 106.67 & 49.90 & 103.67 & 50.73 & 96.67 & 48.70 & 96.67 \\
\hline Cyprus & 39.37 & 104.67 & 42.00 & 95.33 & 44.40 & 81.67 & 39.37 & 88.00 \\
\hline Latvia & 38.73 & 56.00 & 41.17 & 56.67 & 37.90 & 63.00 & 37.80 & 66.33 \\
\hline Lithuania & 39.43 & 59.67 & 40.43 & 65.33 & 35.10 & 74.00 & 33.80 & 77.67 \\
\hline Hungary & 49.80 & 62.33 & 49.33 & 65.67 & 50.37 & 68.00 & 46.97 & 69.00 \\
\hline Malta & 41.87 & 79.67 & 41.67 & 82.67 & 40.83 & 89.00 & 36.37 & 96.67 \\
\hline Netherlands & 44.33 & 139.00 & 47.17 & 134.33 & 45.60 & 132.00 & 42.70 & 128.00 \\
\hline Austria & 51.07 & 125.67 & 51.63 & 128.67 & 51.70 & 130.00 & 49.27 & 127.33 \\
\hline Poland & 43.90 & 55.67 & 44.20 & 64.67 & 42.23 & 67.33 & 41.30 & 69.00 \\
\hline Portugal & 46.67 & 81.33 & 50.27 & 78.00 & 49.93 & 76.33 & 44.57 & 77.00 \\
\hline Romania & 38.17 & 48.67 & 38.93 & 52.33 & 35.60 & 55.00 & 34.43 & 62.33 \\
\hline Slovenia & 45.97 & 87.33 & 50.17 & 83.00 & 53.27 & 82.00 & 44.60 & 85.00 \\
\hline Slovakia & 39.27 & 69.67 & 41.53 & 75.33 & 43.80 & 77.00 & 42.00 & 72.33 \\
\hline Finland & 49.53 & 119.67 & 54.33 & 117.00 & 56.87 & 111.67 & 54.13 & 110.33 \\
\hline Sweden & 50.73 & 126.67 & 50.40 & 127.67 & 50.73 & 125.67 & 49.60 & 121.67 \\
\hline United Kingdom & 44.13 & 111.00 & 46.27 & 108.33 & 43.10 & 109.67 & 41.20 & 106.33 \\
\hline Iceland & 47.50 & 130.00 & 45.27 & 118.33 & 42.53 & 123.00 & 43.17 & 129.33 \\
\hline Norway & 42.93 & 178.67 & 44.30 & 179.33 & 46.67 & 171.33 & 50.40 & 147.00 \\
\hline Switzerland & 31.73 & 158.33 & 33.03 & 161.67 & 34.00 & 165.00 & 34.03 & 156.67 \\
\hline
\end{tabular}

${ }^{*}$ GDP per capita in PPS - Index (EU28 = 100)

Source: Based on the data from (Official site of the Statistical Office of the European Com-mission. URL: http://ec.europa.eu/eurostat)

production processes and the citizens' welfare. The liberal model is characterized by a significant role of market mechanisms of self-regulation. Depending on the cyclical nature of economic processes and the dynamics of social transformation, a particular model is inherent in a particular country at the appropriate stage of its development. The role of state regulation is enhanced in the context of intensified crisis processes. In the context of achieving macroeconomic stability and resilience, the transition to a liberal model begins. In general, this affects the government spending structure. In particular, during 2010-2018, the largest share of government spending in the GDP of the EU countries is social assistance and remuneration. The share of capital investments is about 3\% (Table 2).
The key objective of the EU fiscal strategy for budget expenditures is to create the conditions for innovation, in particular by increasing public investment in $\mathrm{R} \& \mathrm{D}$. However, if the change in private investment occurs by cyclical patterns to changes in GDP, then the change in budget investment is anti-cyclical. This contributes to stimulating economic growth and creating the conditions for encouraging private investment. In particular, in 2008-2009, the vast majority of the EU countries increased the share of government spending on R\&D in the overall spending structure.

At the same time, transformations in the EU's fiscal policy are underway to find a better model for socio-economic development and government spending structure. The coordination of fiscal 
Table 2

The share of government spending in GDP in EU countries, \%

\begin{tabular}{|l|c|c|c|c|}
\hline \multicolumn{1}{|c|}{ Indicators } & $2010-2012$ & $2013-2015$ & $2016-2018$ & $2010-2018$ \\
\hline Intermediate consumption & 6.20 & 6.17 & 5.93 & 6.10 \\
\hline Wages & 10.67 & 10.27 & 9.97 & 10.30 \\
\hline Repayment of interest & 2.83 & 2.47 & 1.97 & 2.42 \\
\hline Subsidies & 1.30 & 1.33 & 20.60 & 2.33 \\
\hline Social assistance & 20.97 & 21.07 & 2.43 & 2.53 \\
\hline Other operating costs & 2.57 & 2.60 & 1.03 & 1.20 \\
\hline Capital debt transfers & 1.43 & 1.13 & 2.77 & 3.00 \\
\hline Capital expenditures & 3.30 & 2.93 & 46.03 & 47.72 \\
\hline Total & 49.23 & 47.90 & Un & \\
\hline
\end{tabular}

Source: Based on the data from (Official site of the Statistical Office of the European Com-mission. URL: http://ec.europa.eu/eurostat)

policy on economic policies was highlighted as a whole. Financial-budget transformations envisage optimization of "unproductive" expenditures and increase of "productive" expenditures of the public sector. This implies the development of an effective model for assessing changes in the level and rate of economic growth. The ways of implementing fiscal policy in the EU countries are somewhat coordinated, but each country applies its fiscal tools, including expenditures budgeting based on national programs.

\section{Features of formation of budget expenditures in the system of fiscal regulation of Ukraine}

According to the data in Table 3, Ukraine refers to the number of countries where a relatively low share of GDP is redistributed through the budget. In particular, the share of expenditures of the consolidated budget of Ukraine in GDP is $34.11 \%$ for $2007-2018$, including $34.19 \%$ for $2010-2012,34.14 \%$ for $2013-2015,35.28 \%$ for 2016-2018 (Table 3). These figures are lower than in the majority of EU countries. At the same time, a significant share in the structure of expenditures of the consolidated budget of Ukraine is made by expenditures for the human potential development (for 2010-2018 $20.25 \%$ in GDP).
Thus, the degree of centralization of Ukraine's public financial resources is not high compared to the EU countries. At the same time, based on foreign experience, high rates of economic growth are observed at much lower values of the share of government spending in GDP. This justifies the proposition that long-term fiscal sustainability should be assessed based on the thresholds of both budgetary architectures of expenditures and revenues. Considering the share of the public sector and the role of public finances in regulating socio-economic processes, in the situation of complicated geopolitical circumstances in Ukraine, financial and economic crisis phenomena, in our opinion, the share of expenditures of the consolidated budget should not exceed $40 \%$. Even though this level has passed almost all the leading foreign countries, the fiscal strategy of which is aimed at accelerating economic growth and improving the welfare of citizens. Accordingly, based on the marginal value of the budget deficit defined in the Maastricht Treaty of $3 \%$ of GDP, the share of Ukraine's consolidated budget revenues should not exceed $37 \%$ of GDP.

Taking into account the significant share in the structure of expenditures of the consolidated budget of Ukraine, expenditures for the development of human potential, the significant fiscal indicator is a measure that characterizes the general government solvency in the long

Table 3

Share of expenditures of consolidated budget of Ukraine in GDP, \%

\begin{tabular}{|l|c|c|c|c|}
\hline \multicolumn{1}{|c|}{ Functional classification } & $2010-2012$ & $2013-2015$ & $2016-2018$ & $2010-2018$ \\
\hline State administration & 3.94 & 5.00 & 5.53 & 4.83 \\
\hline Defense & 1.03 & 1.79 & 2.57 & 1.80 \\
\hline Public order, security and the judiciary & 2.59 & 2.77 & 3.10 & 2.82 \\
\hline Economic activity & 4.52 & 3.17 & 3.43 & 3.71 \\
\hline Environmental protection & 0.31 & 0.29 & 0.25 & 0.29 \\
\hline Housing and communal services & 0.88 & 0.83 & 0.86 & 0.86 \\
\hline Health care & 4.01 & 3.80 & 3.29 & 3.70 \\
\hline Spiritual and physical development & 0.95 & 0.88 & 0.78 & 0.87 \\
\hline Education & 7.07 & 6.43 & 5.77 & 6.42 \\
\hline Social protection and social security & 8.89 & 9.18 & 9.71 & 9.26 \\
\hline Total & 34.19 & 34.14 & 35.28 & 34.54 \\
\hline
\end{tabular}

Source: Based on the data from (Ministry of Finance of Ukraine. URL: https://minfin.gov.ua) 
term (assuming implementation of established priorities of social and economic development). Because the spectrum of relevant priorities is reflected in the structure of budget expenditures. According to the fiscal strategy of Ukraine, the main directions in this area include: accelerating economic growth by creating conditions for the development of a favorable investment climate and ensuring macroeconomic stability; determining at the appropriate level the state social guarantees and standards in the population's income, in the sphere of housing and communal services, household, social and cultural services, health care, education, etc.; creating favorable conditions for the business environment, which will increase investment in innovation; enhancing the competitiveness of human capital (Budget Declaration of Ukraine on 2020-2022, 2019).

These strategic priorities are specified in the annual messages of the President of Ukraine to the Verkhovna Rada of Ukraine "On the Internal and External Situation of Ukraine". The messages underline the importance of addressing issues both in improving the efficiency of the national economy and the welfare of citizens, which is in line with the strategic priorities of the socio-economic development of the EU countries. In particular, according to the strategy "Europe 2020", the main priorities to improve the welfare of the EU countries citizens include: increasing employment; increasing the share of the population with higher education; reducing the number of people living below the povertyline. The main priorities for improving the efficiency of the national economy are: creating the conditions for the development of a knowledge-based and innovative economy; sustainable growth: creating an economy based on sustainable use of resources, compliance with environmental requirements and promoting competition. The budget expenditures structure is formed following these priorities. At the same time, to ensure its validity, an important task is to estimate the expenditures multiplier and the impact of the expenditures level on GDP.

Therefore, in the current context, it is an important task to strengthen the positive impact of the fiscal strategy for budget expenditures on the economic growth of the country. At the same time, authors use correlation-regression analysis methods to estimate the impact of budget expenditures on economic growth.

Based on the correlation-regression analysis, with the share of consolidated budget expenditures in Ukraine for 2010-2018 growing by 1 percentage point in GDP, real GDP decreases by 3.58 percentage points $(y=-74.14-3.58 x)$, including expenditures on state administration - 7.57 percentage points $(y=87.51-7.57 x)$; defense -7.40 percentage points $(y=92.41-7.40 x) ;$ public order, security and the judiciary -17.13 percentage points $(y=45.30-17.13 x)$; economic activity -0.80 percentage point $(y=64.90-0.80 x)$; environmental protection - 69.97 pp $(y=75.55-69.97 \mathrm{~h})$; housing and communal services -
19.91 percentage points $(y=91.24-19.91 x)$; health care 11.04 percentage points $(c=55.20-11.04 \mathrm{~h})$; spiritual and physical development -39.23 percentage points $(\mathrm{y}=58.09-39.23 \mathrm{x})$; education -4.37 percentage points $(y=49.32-4.37 x)$; social protection and social security-4.42percentagepoints $(=40.61-4.42 \mathrm{x})$. Theresults show that budget expenditures are not adversely affected by economic growth. Economic activity expenditures have the most beneficial effect on economic growth.

Thus, the budget expenditures structure has to be assessed in terms of contribution to the achievement of the strategic objectives of socio-economic development. Accordingly, a significant task is to develop an effective methodology for assessing expenditures and to increase the responsibility of public authorities for the reliability of relevant financial and economic justifications. Making rational management decisions on budgeting should be ensured not only by analyzing trends and the dynamics of their use but also by strategically modeling their impact on socio-economic processes.

\section{Conclusions}

The conducted research makes it possible to determine that the fiscal strategy for budget expenditures is a complex, adaptive system of directions and tasks of public authorities in the sphere of budget expenditures formation for socio-economic transformations. It aims at improving the citizens' welfare and the efficiency of the national economy; the intensification of globalization processes leads to the emergence of a large spectrum of both objective and subjective factors that adversely affect the effectiveness of a fiscal strategy for budget expenditures.

The study of the peculiarities of fiscal priorities and strategic directions of the socio-economic development of Ukraine and EU countries proves that they are largely similar. At the same time, analysis and estimation of budget expenditures and government spending show significant differences in the ways of their optimization. To accelerate economic growth, EU countries are changing the structure of government spending in favor of productive ones, while optimizing unproductive ones. In particular, there is an increase in government capital investment. Summarizing and systematizing the experience of EU countries has revealed that long-term fiscal sustainability should be assessed based on a system of thresholds for both budget expenditures and revenues.

At the same time, the most important indicator (the threshold of which justifies the economically feasible degree of public financial resources centralization) is the share of government revenues, not spending in GDP; the increase in government spending should not exceed GDP growth. Therefore, future studies should be conducted on the search for new scientific approaches to develop a fiscal strategy for budget expenditures, taking into account the peculiarities of the development of public relations. 


\section{References:}

Alesina, A., \& Ardagna, S., Perotti, R., \& Schiantarelli, F. (1999). Fiscal Policy, Profits, and Investment. NBER Working Papers, no. 7207. doi: 10.3386/w7207

Atems, B. (2019). The effects of government spending shocks: Evidence from U.S. states. Regional Science and Urban Economics, vol. 74, pp. 65-80. doi: 10.1016/j.regsciurbeco.2018.11.008

Barbiero, O., \& Cournède, B. (2013). New Econometric Estimates of Long-Term Growth Effects of Different Areas of Public Spending. OECD Economics Department Working Papers, no. 1100,15 p. doi: $10.1787 / 5 \mathrm{k} 3 \mathrm{t} x n 15 \mathrm{~b} 59 \mathrm{t}-\mathrm{en}$

Barro, R. J. (1996). Determinants of Economic Growth: A Cross-Country Empirical Study. NBER Working Papers, no. 5698. doi: $10.3386 /$ w5698

Burge, G. S. \& Rogers, C. L. (2011). Local option sales taxes and consumer spending patterns: Fiscal interdependence under multi-tiered local taxation. Regional Science and Urban Economics, vol. 41.1, pp. 46-58. doi: 10.1016/ j.regsciurbeco.2010.08.001

Dupaigne, M., \& Fève, P. (2016). Persistent government spending and fiscal multipliers: The investment-channel. European Economic Review, vol. 89, pp. 425-453. doi: 10.1016/j.euroecorev.2016.09.004

Felice, G. (2016). Size and composition of public investment, sectoral composition and growth. European Journal of Political Economy, vol. 44, pp. 136-158. doi: 10.1016/j.ejpoleco.2016.07.001

Flavin, P. (2019). State government public goods spending and citizens' quality of life. Social Science Research, vol. 78, pp. 28-40.

Glocker, C., Sestieri, G., \& Towbin, P. (2019). Time-varying government spending multipliers in the UK. Journal of Macroeconomics, vol. 60, pp. 180-197. doi: 10.1016/j.jmacro.2019.02.003

$\mathrm{Hu}, \mathrm{R} .$, \& Zarazaga, C. E. (2018). Fiscal stabilization and the credibility of the U.S. budget sequestration spending austerity. Journal of Economic Dynamics and Control, vol. 93, pp. 54-66. doi: 10.1016/j.jedc.2018.02.010

Kim, W. (2019). Government spending policy uncertainty and economic activity: US time series evidence. Journal of Macroeconomics, vol. 61, pp. 103-124. doi: 10.1016/j.jmacro.2019.103124

Lin, B., \& Zhu, J. (2019). Fiscal spending and green economic growth: Evidence from China. Energy Economics, vol. 83, pp. 364-271. doi: 10.1016/j.eneco.2019.07.010

Liu, D., Xu, C., Yu, Y., Rong, K., \& Zhang, J. (2019). Economic growth target, distortion of public expenditure and business cycle in China. China Economic Review, 101373. doi: 10.1016/j.chieco.2019.101373

López, R. E., Galinato, G. I., \& Islam, A. (2011). Fiscal spending and the environment: Theory and empirics. Journal of Environmental Economics and Management, vol. 62(2), pp. 180-198. doi: 10.1016/j.jeem.2011.03.001

Lucas, R. E. (1988). On the Mechanics of Economic Development. Journal of Monetary Economics, vol. 22.1, pp. 3-42. doi: 10.1016/0304-3932(88)90168-7

Ministry of Finance of Ukraine (n.d.). Official site of Ministry of Finance of Ukraine. Retrieved from: ttps://minfin.gov.ua

Nam, J. (2019). Government spending during childhood and intergenerational income mobility in the United States. Children and Youth Services Review, vol. 100, pp. 332-343. doi: 10.1016/j.childyouth.2019.03.017

Official site of the Statistical Office of the European Commission. Retrieved from: http://ec.europa.eu/eurostat

Olanubi, S. O., Osode, O. E., \& Adegboye, A. A. (2019). Public sector efficiency in the design of a euro-area social benefit scheme. Journal of Policy Modeling. doi: 10.1016/j.jpolmod.2019.10.001

Pasichnyi, M. (2017). Empirical study of the fiscal policy impact on economic growth. Problems and perspectives in management, vol. 15, Iss. 3 (contin. 2), pp. 316-322. doi: 10.21511/ppm.15(3-2).2017.01

Pasichnyi, M., Kaneva, T., Ruban M., \& Nepytaliuk, A. (2019). The impact of fiscal decentralization on economic development. Investment Management and Financial Innovations, vol. 16(3), pp. 29-39. doi: 10.21511/ imfi.16(3).2019.04

Pop Silaghi, M. I., Alexa, D., Jude, C., \& Litan, C. (2014). Do business and public sector research and development expenditures contribute to economic growth in Central and Eastern European Countries? A dynamic panel estimation. Economic Modelling, vol. 36, pp. 108-119. doi: 10.1016/j.econmod.2013.08.035

Ricco, G., Callegari, G., \& Cimadomo, J. (2016). Signals from the government: Policy disagreement and the transmission of fiscal shocks. Journal of Monetary Economics, vol. 82, pp. 107-118. doi: 10.1016/ j.jmoneco.2016.07.004

Roşoiu, I. (2015). The Impact of the Government Revenues and Expenditures on the Economic Growth. Procedia Economics and Finance, vol. 32, pp. 526-533. doi: 10.1016/S2212-5671(15)01428-8

The Euro Plus Pact (2011). Retrieved from: http://ec.europa.eu/epsc/pdf/publications/strategic_note issue_3.pdf

The Long-Term Sustainability of Public Finances in the European Union (2006). European Economy, vol. 4, pp. $1-226$. 
The Quality of Public Expenditures in the EU (2012). European Economy Occasional Papers.125. Retrieved from: https://ec.europa.eu/economy_finance/publications/occasional_paper/2012/pdf/ocp125_en.pdf

Yong, C., \& Dingming, L. (2019). How does government spending news affect interest rates? Evidence from the United States. Journal of Economic Dynamics and Control, vol. 108, 103747. doi: 10.1016/j.jedc.2019.103747

Biudzhetna deklaratsiia Ukrainy na 2020-2022 rr. [Budgetary Declaration of Ukraine for 2020-2022]. Retrieved from: http://nizhyn-budget.org/static/file/budzetna-deklaracia-na-2020-2022-roki.pdf

Orlov, M. F., Speranskiy, M. M., \& Turgenev, N. I. (1998). U istokov finansovoho prava [At the origins of financial law]. Moskva: Statut. 